\title{
Translation Analysis on the Dayak Cultural Terms from Dayak Ngaju to Indonesian and English
}

\author{
Lida Karyani ${ }^{1}{ }^{*}$, M. R. Nababan ${ }^{2}$; Sri Marmanto ${ }^{3}$ \\ ${ }^{1}$ Universitas Sebelas Maret, Indonesia, Balai Bahasa Kalimantan Tengah. Email: lidakaryani@gmail.com \\ ${ }^{2}$ Universitas Sebelas Maret, Indonesia. Email:amantaradja@yahoo.com \\ ${ }^{3}$ Universitas Sebelas Maret, Indonesia. Email: marmanto@staff.uns.ac.id \\ *corresponding author
}

\section{ARTICLE INFO}

Keywords:

Dayak cultural term; Tatum; translation techniques;

translation quality

How to cite:

Karyani, L., Nababan, M.R., \& Marmanto, S. (2020).

Translation Analysis on the Dayak Cultural Terms from Dayak Ngaju to Indonesian and English. Langkawi: Journal of The Association for Arabic and English, 6(1), 4154.

DOI:

http://dx.doi.org/10.31332/ $\underline{\text { lkw.v6i1.1676 }}$

\begin{abstract}
The research aims to describe the translation techniques and translation qualities of the Dayak cultural terms. The data were obtained from Tatum, an oral culture of Dayak transcribed and rewritten in Dayak Ngaju, Indonesian and English in a book entitled The Ot Danum from Tumbang Miri until Tumbang Rungan. The research used descriptive qualitative method with content analysis. It aims to explain the translation techniques and translation qualities of the Dayak cultural terms translated from Dayak Ngaju to Indonesian and from Indonesian to English. The Dayak cultural terms analyzed were related to the organization, the customs, the belief, and the kinship system of Dayak. The translation techniques of the Dayak cultural terms from Dayak Ngaju to Indonesian were pure borrowing, naturalized borrowing, established equivalent, generalization, variant borrowing, description, and amplification, and the translation qualities were 2.80 of accuracy and 2.84 of acceptability. The Dayak cultural terms found in the target language (Indonesian translation) were decreased in number as the effect of the translation techniques used. The translation technique of Dayak cultural terms from Indonesian to English was pure borrowing, and the translation quality were 3 of accuracy and 2.75 of acceptability.
\end{abstract}

\section{Introduction}

The Dayak tribe in Borneo island is a tribe with oral culture since the manuscripts of the cultural heritage are not found. Besides, among the various regional languages in Indonesia, only nine have letters namely Aceh, Batak, Lampung, Javanese, Balinese, Buginese, Sundanese, Malay and Sasak (Tol, Roger, \& Pudentia, 1994). Dayak oral culture includes folklores, songs, proverbs, traditional medicines, rituals, arts, etc. In the past, these forms of oral culture were inherited from previous generations naturally. This cultural inheritance depends on memory. Nowadays, it does not occur successfully due to significant changes in culture. Modernization gradually reduces indigenous cultures.

Dayak Ngaju is one of the Dayak sub-ethnics in Central Borneo. The oral culture of Dayak Ngaju is gradually forgotten. To preserve it, many researchers have tried to document the cultures. They are Sistem Fonologi Bahasa Dayak Ngaju (Ristati, 2006), Tata Bahasa Dayak Ngaju (Sigiro, dkk, 2013) Kamus Dwibahasa Dayak NgajuIndonesia (Suryanyahu \& Dkk, 2013), Sastra Lisan Dayak Ngaju (Andianto, Mihing, \& 
Uan, 1987), Petatah-Petitih dalam Bahasa Dayak Ngaju (Iper, Jumiati, \& Limin, 1997), Paralisme Semantik dalam Teks Ritual (Sumpah Adat) Tawur Hasapa (Suryanyahu, 2009), etc.

However, research on the translation on Dayak Ngaju language and culture seems to be rare, especially related to the translation processes and translation products. This is due to the small number of translation works, either Dayak Ngaju to Indonesian language or other languages (e.g. English). Particularly concerning cultural texts, differences in language systems and cultures become a massive challenge in translating cultural texts. Catford in Irwan (Irwan, Putra, \& Rahmadani, 2018) suggests that translation is changing a text in one language (source language) into an equivalent text in another language (target language). Somehow, translating cultural texts often renders difficulties due to the absence of equivalent words in the target language.

Several researchers have attempted to research cultural text translation. They focus on the indigenous languages in Indonesia. Simarmata (2015) on his thesis entitled Analisis Teknik Penerjemahan dan Kualitas Terjemahan Istilah-istilah Budaya Bahasa Inggris ke dalam Bahasa Batak Toba yang Terdapat pada Dubbing Film Jesus investigates translation techniques and quality of cultural terms from English into Batak Toba language. He found the use of translation techniques impacted the translation quality of cultural terms. And the translation quality he concerned about was the acceptability aspect of the cultural term translation. Besides, he also classified Batak Toba cultural terms into Koentjaraningrat's cultural terms category.

Nugrahani, Nababan, Santosa, \& Djatmika (2019) on their article entitled 'Translating Javanese Culture Expressions in a Novel' had accounted translation study on Javanese cultural expressions in Indonesian novel translated into English. The study focuses on identifying translation techniques and quality. The research indicates that the appropriate techniques in translating Javanese cultural expressions result in a good quality translation.

Jarob, Sujaini, dan Safriadi (2016) with "Assessing Accuracy on Indonesian Dayak Taman Translation by Tagging Base Words and Affixes" use a translation product research with statistical machine translation. They use tagging on each word by obtaining its base words and affixes to assess the accuracy of statistical machine translation from Indonesian - Dayak Taman. Dayak Taman is a sub-ethnic of Dayak, residing in Kapuas upstream, West Borneo.

The above pieces of research are focusing on translation products of the indigenous languages and cultures in Indonesia. However, translation research on Dayak indigenous languages and culture seems not to be the concern of the researchers in Central Borneo.

The present research investigates Dayak Ngaju cultural terms which focuses on the organization, the custom, and the idea based on Newmark's cultural words categorization. The study focuses on translation techniques and qualities of Dayak cultural terms from Dayak Ngaju to Indonesia and from Indonesia to English. Thus, the translation is a relay translation.

The present research is considered significant since it is useful for further translation research on Dayak indigenous languages and cultures. Moreover, translation is also considered as an effort to preserve indigenous languages and oral 
cultures as it documents them. It also becomes a means to introduce various indigenous languages and cultures in Indonesia to the world.

Before analyzing the translation techniques and qualities, researcher classified Dayak cultural terms into Newmarks's cultural words categorization which are divided into five categories, those are: 1) ecology, 2) material culture, 3) social culture, 4) organization; customs, ideas, and 5) gestures and habits. This present study focuses on the category number four. In analyzing translation technique and qualities, the present research utilizes some fundamental theories. Translation techniques were analyzed based on Molina and Albir theory (Molina \& Albir, 2002). They are adaptation, amplification, borrowing, calque, compensation, description, discursive creation, established equivalent, generalization, linguistic amplification, linguistic compression, literal translation, modulation, particularization, reduction, substitution, transposition, and variation. Besides, the researcher used Translation Quality Assessment (TQA) proposed by Nababan, Nuraeni, dan Sumardiono (2012). The model of TQA assesses the translation quality and is applicable for assessing translation quality in the translation research context. There are three aspects in assessing translation quality, including accuracy, acceptability, and readability. A good quality translation has to fulfil those aspects. However, the present study is limited in accuracy and acceptability.

Accuracy is a term used to evaluate translation referring to whether source text and target text have been equivalent or not (Nababan et al., 2012). Equivalence indicates the similarity of the message containing in the source text and target text. The indicator for assessing the accuracy level is between $1-3$, in which three is for accurate (A), 2 is for less accurate (LA), and 1 is for inaccurate (IA). "Accurate" means words, phrases, clauses, or specific terms conveyed accurately to the target language, and no meaning distortion occurred at all. "Less accurate" means some words, phrases, clauses, or specific terms conveyed accurately to target language but some meaning distortions and ambiguity in the translation occurred. And, "inaccurate" means words, phrases, clauses, or specific terms inaccurately conveyed to target language and deletion of a message from the source language to target language exists. These indicators are fundamental for scoring or assessing accuracy.

The acceptability refers to the appropriateness toward the grammatical system, norms, and culture in the target language (Nababan et al., 2012). It is also related to principles of certain text translated. For example, literary works have to be translated into a similar language style unless it becomes unacceptable. The indicator for assessing the acceptability is between $1-3$, in which three is for acceptable (A), two is for less acceptable (LA), and 1 is for inacceptable (IA). "Acceptable" means the translation is natural, specific terms used are common to target reader, and phrase or clauses are grammatically correct in the target language. "Less acceptable" means the translation is natural, but some grammatical error in target language happened. And, inacceptable means the translation is not natural, specific terms used are not common to target reader, and phrases or clauses are not in accordance with target language grammatical rules. These indicators are fundamental for scoring or assessing the acceptability.

\section{Method}

The present research is a translation study on a book entitled The Ot Danum from Tumbang Miri until Tumbang Rungan (Nahan \& Rampai, 2010). The researcher 
employs a descriptive qualitative method since it describes the linguistic phenomena in translation techniques and qualities of Dayak cultural terms.

Location, as proposed by Spradley (2006), needs to fulfil three basic elements, including participants, setting, and events. These elements were fulfilled in this folklore and able to become the elements of the research location.

The data of the study were obtained from the oral culture of Dayak Ngaju in the form of folklore, which is called Tatum. Tatum is a cultural text which refers to the myth about the origin of Dayak tribe in Central Borneo, sung or delivered mountingly. As a cultural text, Tatum contains cultural terms related to histories and local wisdom such as belief, customary laws, art, and rituals. As a form of oral tradition, Tatum had been transcribed into Dayak Ngaju language (DNL), and translated into Indonesian language (IL), and retranslated from the Indonesian language into English (EL). It had been written in a book entitled The Ot Danum from Tumbang Miri until Tumbang Rungan (Nahan \& Rampai, 2010). The data, as proposed by Sutopo (2002), were in terms words, sentences, or pictures containing meaning and able to reveal more real understanding than numbers and frequencies.

The researcher used content analysis, interview, and focus group discussion (FGD) as data collection techniques. Content analysis is used to obtain the data. An interview is conducted with three experts of Dayak language and culture to validate the data and obtain the meaning of Dayak cultural terms. And, FGD involving raters who are experts in translation study is conducted to identify translation techniques and assess translation qualities. The researcher is involved in FGD. FGD is used to obtain the objectivity of quality translation assessment.

\section{Findings}

Dayak Ngaju language (DNL) is the source language which is then translated into the Indonesian language (IL), and the Indonesian translated version is translated into English language (EL). Hence, the present research identifies translation techniques of Dayak cultural terms (DCT) from DNL to IL and IL to EL.

\subsection{Translation Techniques of Dayak Cultural Terms from Dayak Ngaju into Indonesian}

In source text (DNL), the research finds 25 DCT in the organization; the custom; the ideas category. The DCT related to the religion and the kinship system is included in the ideas. The data are distributed into two data of the organization, ten data of the custom, eleven data of the religion, and two data of the kinship system.

After obtaining and classifying the data, the research identifies translation techniques. It indicates seven techniques used for translating DCT from DNL to IL. They are pure borrowing, established equivalent, generalization, amplification, variant borrowing, naturalized borrowing, and description. The translation techniques and examples are as follows.

\subsubsection{Pure borrowing}

This technique is the most frequent technique used, taking up to fourteen occurrences. They are represented in the following examples. 
Data 1:

DNL: Uras uluh Dayak mimbing ije kayakinan ie te tatu hiang ewen dumah bara langit je impamuhun kan batang danum kalunen mahapan palangka bulau intu epat eka.

IL: $\quad$ Seluruh orang Dayak berkeyakinan bahwa nenek moyang mereka berasal dari langit yang diturunkan ke dunia dengan wadah emas (sekaligus merupakan kendaraan angkasa) di empat tempat.

Dayak is a term related to organization since it refers to the community of Dayak people. The sentence means that all Dayak people believed that their ancestors came from heaven, went down to the world with the gold container (as well as a sky vehicle) in four places.

\subsubsection{Generalization}

This technique occurs four times amongst 25 data.

Data 2:

DNL: Awi amun ie hagerek te uluh beken je malihi, hengga Etak tapaksa harajur baurusan helu hagan manahur sahiring akan genep biti uluh je balaku ganti pampatei babuhaa

IL: $\quad$ Karena jika ia bergerak maka orang lain yang meninggal, sehingga Etak terpaksa selalu harus berurusan dahulu untuk membayar denda bagi setiap orang yang menuntut kematian warganya.

Manahur sahiring is a term related to the custom of Dayak people. The sentence means that because if s/he moved, others died, so Etak was forced to always firstly concern about paying a fine for each who demanded his/her people death.

\subsubsection{Established equivalent}

This technique occurs three times amongst 25 data.

Data 3:

DNL : Awi kanahuang Ranying Hatalla Langit (Hatalla) hayak palangka bulau te impamuhun ih ije hatue (sabujure Sangiang atawa dewa) bagare Antang Bajela Bulau (manumun Tatum) atau Tunggul Garing Janjahunan Laut (manumun Mahanteran, huang upacara pampatei Tiwah) intu Tantan Puruk Pamatuan, ije pamatang helat hulu batang danum Kahayan tuntang hulu batang danum Barito.

IL: Atas kehendak Ranying Hatalla Langit (Tuhan) dengan wadah emas itu diturunkanlah seorang lelaki (sebenarnya Sang Hyang atau dewa) bernama Antang Bajela Bulau (menurut Tatum) atau Tunggul Garing Janjahunan Laut (menurut Mahanteran, dalam upacara kematian Tiwah) di Puncak Bukit Pamatuan, suatu dataran tinggi antara hulu sungai Kahayan dan sungai Barito.

Hatalla is a term related to the indigenous belief of Dayak Ngaju people. The sentence means that by Ranying Hatalla Langit (God)'s will, He sent a man (who as Sang Hyang or God) down, Antang Bajela Bulau (based on Tatum) or Tunggal Garing Jajahunan Laut (based on Mahanteran, in Tiwah's death wail) by using the golden vehicle in the top of Pamatuan Hill, a plateau between Kahayan and Barito rivers. 
Lida Karyani, M.R. Nababan, Sri Marmanto: Translation Analysis on the Dayak Cultural Terms...

\subsubsection{Amplification}

This technique is reflected in one datum.

Data 4:

DNL: Genep bitin ewen jadi mahalau masa karung lawang bawi kuwu.

IL: $\quad$ Setiap orang mereka itu telah menjalani masa dididik dalam pingitan.

Karung lawang bawi kuwu is a term related to custom of Dayak Ngaju people. The sentence means that each person has gone through educated period in the seclusion.

\subsubsection{Description}

The technique found in one datum.

Data 5:

DNL: Kawan tabela te dia beken bara paharii jitatu, hanjenan tuntang hararue haream hayak kakare aken ewen kabuat je dumah bara ngaju tuntang bara ngawa (lewu Tumbang ftiri hingga lewu Tumbang Rungan).

IL: $\quad$ Para pemuda itu tidak lain dari saudara- saudaranya sepupu sekali, sepupu dua dan malah sepupu tiga serta kemenakan mereka sendiri yang datang dari hulu dan dari hilir (desa Tumbang Miri sampai desa Tumbang Rungan).

Hararue is a term related to the kinship system of Dayak Ngaju. The sentence means that those boys were absolutely from their once remove cousin, twice removed cousin, and even three times removed cousin as well as their nephews and nieces arriving from the upstream and the downstream (from Tumbang Miri subdistrict to Timbang Rungan subdistrict).

\subsubsection{Naturalized Borrowing}

This technique is applied to one datum.

Data 6:

DNL: Papire nyelu limbah kajadian badaha te, tahining kabar je uluh bara batang danum Mahakam te je katutu lewu Rangan Pulang, handak haguet mangayau (gawi ije biti atawa baare je kajam, manetek takuluk musuhe) ...

IL: Beberapa tahun kemudian setelah kejadian berdarah itu, terdengar berita bahwa orang-orang dari sungai Mahakam itu sebenarnya desa Rangan Pulang, akan pergi mengayau (perbuatan seseorang atau lebih yang kejam, memotong kepala musuhnya) ...

Mangayau is a term related to the custom of Dayak people in Borneo. The sentence means that several years after that bloody event, there was a news that people from Mahakam river, who are genuinely Rangan Pulang people, would go decapitation (a cruel act of beheading enemy's head) to take a revenge to Rangan Marau.

\subsubsection{Variant borrowing}

This technique has been proposed by Nugrahani et al. (2019). It is applied in one datum amongst 25.

Data 7:

DNL: Awi kanahuang Ranying Hatalla Langit (Hatalla) hayak palangka bulau te impamuhun ih ije hatue (sabujure Sangiang atawa dewa) bagare Antang Bajela Bulau (manumun Tatum) atau Tunggul Garing Janjahunan Laut 
(manumun Mahanteran, huang upacara pampatei Tiwah) intu Tantan Puruk Pamatuan, ije pamatang helat hulu batang danum Kahayan tuntang hulu batang danum Barito.

IL: Atas kehendak Ranying Hatalla Langit (Tuhan) dengan wadah emas itu diturunkanlah seorang lelaki (sebenarnya Sang Hyang atau dewa) bernama Antang Bajela Bulau (menurut Tatum) atau Tunggul Garing Janjahunan Laut (menurut Mahanteran, dalam upacara kematian Tiwah) di Puncak Bukit Pamatuan, suatu dataran tinggi antara hulu sungai Kahayan dan sungai Barito.

Sangiang is a term related to the indigenous belief of Dayak Ngaju. The sentence means that by Ranying Hatalla Langit (God)'s will, He sent a man (who was Sang Hyang or God) down, Antang Bajela Bulau (based on Tatum) or Tunggal Garing Jajahunan Laut (based on Mahanteran, in Tiwah's death wail) by using the golden vehicle in the top of Pamatuan Hill, a plateau between Kahayan and Barito rivers.

\subsection{Translation Quality of Dayak Cultural Term from Dayak Ngaju to Indonesian}

Translation qualities are determined by three aspects (accuracy, acceptability, and readability) (Nababan et al., 2012). Yet, the research is limited in two aspects, including accuracy and acceptability. To find out the accuracy and acceptability of translated Dayak cultural terms, the researcher interviewed the Dayak Ngaju language and culture experts. Then, an FGD was also conducted to assess whether the translated DCT had been accurate/ less accurate/ inaccurate, and acceptable/ less acceptable/ unacceptable. The definition of accurate/less accurate/inaccurate, and acceptable/less acceptable/unacceptable has been mentioned in introduction section.

\subsubsection{Accuracy}

Accuracy refers to the equivalence of messages between source language and target language. In the accuracy aspect, there are three parameters of assessment, including 3 for accurate (A), 2 for less accurate, and 1 for inaccurate (IA). There are 20 accurate translations, five less accurate translations, and none inaccurate translation of DCT. The examples are as follows.

a) Accurate Translation

Data 1:

DNL: Hapan kasaktii Antang Bajela Bulau mawi due hatue je inggaree Lambung tuntang Lanting (huang Mahanteran ewen te Maharaja Bunu tuntang Maharaja Sangen)

IL: Dengan kesaktiannya Antang Bajela Bulau menciptakan dua orang lelaki yang dinamainya Lambung dan Lanting (dalam Mahanteran mereka itu adalah Maharaja Bunu dan Maharaja Sangen)

The sentence means that by his divine power, Antang Bajela Bulau created two men, namely Lambung and Lanting (in Mahanteran, they were Maharaja Bunu and Maharaja Sangen). The translation of Mahanteran is considered accurate since it is transferred from source language by borrowing technique thus no meaning distortion in the target language occurred. 
b) Less Accurate Translation

Data 2:

DNL: Uras uluh Dayak mimbing ije kayakinan ie te tatu hiang ewen dumah bara langit je impamuhun kan batang danum kalunen mahapan palangka bulau intu epat eka.

IL: $\quad$ Seluruh orang Dayak berkeyakinan bahwa nenek moyang mereka berasal dari langit yang diturunkan ke dunia dengan wadah emas (sekaligus merupakan kendaraan angkasa) di empat tempat.

The sentence means that all Dayak people believed that their ancestors came from heaven, went down to the world with the golden pot (as well as a sky vehicle) in four places. Palangka is a vehicle from heaven. The term Palangka which is translated into wadah is considered less accurate since the word wadah does not accommodate the meaning of Palangka accurately.

\subsubsection{Acceptability}

The acceptability refers to the appropriateness toward grammatical system, norms, and culture in target language (Nababan et al., 2012). Similarly, in the acceptability aspects, there are three parameters of assessment, including 3 for acceptable (A), 2 for less acceptable (LA), and 1 for inacceptable (IA). The research finds 21 acceptable translations, four less acceptable translations, and none unacceptable translation of DCT. The examples are as follows.

a) Acceptable translation

Data 3:

DNL: Genep bitin ewen jadi mahalau masa karung lawang bawi kuwu.

IL: $\quad$ Setiap orang mereka itu telah menjalani masa dididik dalam pingitan.

The sentence means that each person has gone through an educated period in the seclusion. The translated term is considered acceptable since it corresponds to target reader grammatical system and norms.

b) Less acceptable translation

Data 4:

DNL: Awi kanahuang Ranying Hatalla Langit (Hatalla) hayak palangka bulau te impamuhun ih ije hatue (sabujure Sangiang atawa dewa) bagare Antang Bajela Bulau (manumun Tatum) atau Tunggul Garing Janjahunan Laut (manumun Mahanteran, huang upacara pampatei Tiwah) intu Tantan Puruk Pamatuan, ije pamatang helat hulu batang danum Kahayan tuntang hulu batang danum Barito.

IL: Atas kehendak Ranying Hatalla Langit (Tuhan) dengan wadah emas itu diturunkanlah seorang lelaki (sebenarnya Sang Hyang atau dewa) bernama Antang Bajela Bulau (menurut Tatum) atau Tunggul Garing Janjahunan Laut (menurut Mahanteran, dalam upacara kematian Tiwah) di Puncak Bukit Pamatuan, suatu dataran tinggi antara hulu sungai Kahayan dan sungai Barito.

The sentence means that by Ranying Hatalla Langit (God)'s will. He sent a man (who was actually Sang Hyang or God) down, Antang Bajela Bulau (based on Tatum) or Tunggal Garing Jajahunan Laut (based on Mahanteran, in Tiwah's death wail) by using a golden vehicle in the top of Pamatuan Hill, a plateau between 
Kahayan and Barito rivers. The translated term Tatum is less acceptable since there is no additional information about the meaning of Tatum in target language. It has caused the translated term less understandable.

The following table shows the translation quality assessment of accuracy and acceptability on Dayak cultural terms from Dayak Ngaju to Indonesian.

Table 1. Average of Translation Quality on Dayak Cultural Terms from Dayak Ngaju to Indonesian

\begin{tabular}{|c|c|c|c|c|c|}
\hline No & $\begin{array}{l}\text { Aspect of } \\
\text { Translation } \\
\text { Quality }\end{array}$ & Data & Frequency & Score & Average Score \\
\hline \multirow[t]{4}{*}{1} & Accuracy & & & & \multirow{4}{*}{$\begin{array}{l}=\frac{(20 \times 3)+(5 \times 2)}{25} \\
=\frac{(60+10)}{25} \\
=\frac{70}{25} \\
=2.80\end{array}$} \\
\hline & a. Accurate & $\begin{array}{c}1,2,5,6,7,8,10 \\
16,17,18,19,28 \\
33,51,59,62,64 \\
\quad 65,66,68\end{array}$ & 20 & 3 & \\
\hline & b. Less Accurate & $2,51,52,66,68$ & 5 & 2 & \\
\hline & c. Inaccurate & - & - & 1 & \\
\hline \multirow[t]{4}{*}{2} & Acceptability & & & & \multirow{4}{*}{$\begin{array}{l}=\frac{(21 \times 3)+(4 \times 2)}{25} \\
=\frac{(63+8)}{25} \\
=\frac{71}{25} \\
=2.84\end{array}$} \\
\hline & a. Acceptable & $\begin{array}{c}1,2,5,6,7,8,10 \\
16,17,18,19,28 \\
33,51,52,59,62 \\
64,65,66,68\end{array}$ & 21 & 3 & \\
\hline & $\begin{array}{l}\text { b. Less } \\
\text { Acceptable }\end{array}$ & $9,11,12,43$ & 4 & 2 & \\
\hline & c. Inacceptable & - & - & 1 & \\
\hline
\end{tabular}

\subsection{Translation Technique of Dayak Cultural Term from Indonesian to English}

Sixteen data on Dayak cultural terms are found in Indonesian version related to the organization, the customs, and the religions. The data are distributed into two data of the organization, five data of the custom, nine data of the religion, and no data of the kinship system.

Only one translation technique is identified in Dayak cultural term translation from Indonesian to English, namely pure borrowing, as shown in the following table. This is an example of the application of pure borrowing:

IL: Atas kehendak Ranying Hatalla Langit (Tuhan) dengan wadah emas itu diturunkanlah seorang lelaki (sebenarnya Sang Hyang atau dewa) bernama Antang Bajela Bulau (menurut Tatum) atau Tunggul Garing Janjahunan Laut (menurut Mahanteran, dalam upacara kematian Tiwah) di Puncak Bukit Pamatuan, suatu dataran tinggi antara hulu sungai Kahayan dan sungai Barito.

EL: By the will of Ranying Hatalla Langit (God), using the golden pot was a man (who was actually a god or Sang Hyang), named Antang Bajela Bulau, (according to Tatum) or Tunggul Garing Janjahunan Laut 
(according to Mahanteran, in the ceremony for the deceased Tiwah) on top of the Pamatuan hill, somewhere between the river of Kahayan and Barito.

From research findings, pure borrowing was identified as the technique to translate DCT from IL to EL. Translator of Tatum might have chosen the technique because there are no equivalent terms in English. Besides, terms related to belief and rituals of Dayak culture are very specific that they cannot be generalized by common terms. Pure borrowing might be a solution to transfer cultural terms to target language when there are no equivalent words to them. Another reason is that pure borrowing can be a way to present culture to target language.

\subsection{Translation Quality of Dayak Cultural Term from Indonesian to English}

As stated before, this research is limited to assessing the translation quality of DCT from IL to EL in terms of accuracy and acceptability.

\subsubsection{Accuracy}

The research shows that all data are translated accurately which means no meaning distortion occurred on the translated DCT. The example is as follows.

Data 1:

IL: Atas kehendak Ranying Hatalla Langit (Tuhan) dengan wadah emas itu diturunkanlah seorang lelaki (sebenarnya Sang Hyang atau dewa) bernama Antang Bajela Bulau (menurut Tatum) atau Tunggul Garing Janjahunan Laut (menurut Mahanteran, dalam upacara kematian Tiwah) di Puncak Bukit Pamatuan, suatu dataran tinggi antara hulu sungai Kahayan dan sungai Barito.

EL: By the will of Ranying Hatalla Langit (God), using the golden pot was a man (who was actually a god or Sang Hyang), named Antang Bajela Bulau, (according to Tatum) or Tunggul Garing Janjahunan Laut (according to Mahanteran, in the ceremony for the deceased Tiwah) on top of the Pamatuan hill, somewhere between the river of Kahayan and Barito.

\subsubsection{Acceptability}

In the acceptability aspect, there are twelve acceptable translations and four less acceptable translations. The translated DCT are acceptable if they are understandable to target readers with cultural differences. The translated DCT is explicitly stated by additional information given in parenthesis. Thus, the whole sentences make them clear. Yet, some of the translated DCT is less acceptable because the target readers cannot comprehend the meanings. For examples:

a) Acceptable Translation

Data 2:

IL: $\quad$ Dipimpin oleh Sempung dilakukan upacara Tahusung Taharang (penyambutan pahlawan) terhadap ketiga puluh orang pemuda tersebut.

EL: Lead by Sempung, they carried out the ceremony of Tahusung Taharang (welcoming the heroes) for the thirty young men. 
b) Less Acceptable Translation

Data 3:

IL: Atas kehendak Ranying Hatalla Langit (Tuhan) dengan wadah emas itu diturunkanlah seorang lelaki (sebenarnya Sang Hyang atau dewa) bernama Antang Bajela Bulau (menurut Tatum) atau Tunggul Garing Janjahunan Laut (menurut Mahanteran, dalam upacara kematian Tiwah) di Puncak Bukit Pamatuan, suatu dataran tinggi antara hulu sungai Kahayan dan sungai Barito.

EL: By the will of Ranying Hatalla Langit (God), using the golden pot was a man (who was actually a god or Sang Hyang), named Antang Bajela Bulau, (according to Tatum) or Tunggul Garing Janjahunan Laut (according to Mahanteran, in the ceremony for the deceased Tiwah) on top of the Pamatuan hill, somewhere between the river of Kahayan and Barito.

The following table represents the assessment on translation quality in terms of accuracy and acceptability of Dayak cultural terms from Indonesian to English.

Table 2. Average Score of Translation Quality of Dayak Cultural Terms from Indonesian to English

\begin{tabular}{|c|c|c|c|c|c|}
\hline No & Quality & Data & Frequency & Score & Avarage score \\
\hline \multirow[t]{4}{*}{1} & Accuracy & & & & \multirow{4}{*}{$\begin{array}{l}=\frac{16 \times 3}{16} \\
=\frac{48}{16} \\
=3,00\end{array}$} \\
\hline & a. Accurate & $\begin{array}{c}1,5,7,8,9,10 \\
11,12,16,17 \\
18,19,28,33 \\
43,59\end{array}$ & 16 & 3 & \\
\hline & b. Less accurate & - & - & 2 & \\
\hline & c. Inaccurate & - & - & 1 & \\
\hline \multirow[t]{4}{*}{2} & Acceptability & & & & \multirow{4}{*}{$\begin{array}{l}=\frac{(12 \times 3)+(4 \times 2)}{16} \\
=\frac{44}{16} \\
=2,75\end{array}$} \\
\hline & a. Acceptable & $\begin{array}{c}1,5,7,8,10,16 \\
17,18,19,28 \\
33,59\end{array}$ & 12 & 3 & \\
\hline & $\begin{array}{l}\text { b. Less } \\
\text { acceptable }\end{array}$ & $9,11,12,43$ & 4 & 2 & \\
\hline & c. Inacceptable & & - & 1 & \\
\hline
\end{tabular}

\section{Discussion}

There are seven translation techniques identified in the DCT translation from DNL to IL. Borrowing technique is mostly used. It is to borrow words or expressions from source language in terms of pure (pure borrowing) or naturalized (naturalized borrowing). Pure borrowing is to borrow words or expressions from source language without any changes. Examples of the data are Dayak and Ranying Hatalla Langit which are translated by pure borrowing technique. Generalization technique uses more general or neutral terms in target language than source language, which is specific. The example is the phrase manahur sahiring which is translated to membayar 
denda. Manahur sahiring means paying a fine for violating customary law. However, In Indonesian version, it is generalized into membayar denda or paying a fine.

Established equivalent technique refers to using common terms or expressions (based on dictionary or daily usage). The word Hatalla is cultural term related to the religion. Dayak people have the indigenous belief called as Kaharingan and called their God as Ranying Hatalla Langit, abbreviated as Hatalla that means God. In Indonesian version, the translator uses Tuhan (God) to transfer Hatalla. Tuhan is considered as a common term to describe God in Indonesian culture. Amplification technique explicates or paraphrases the implicit information in source language. Karung lawang bawi kuwu is derived from karung lawang (bedroom) and bawi kuwu (secluded girl). This is a custom in which Dayak girls go through before marriage. In this period, girls are educated regarding ethic, lifestyle, plait, and other skills. The translator explicates the phrase to make the term more understandable.

Description technique indicates the way of changing a term or expression into description of form, function or meaning. The kinship terms in Dayak Ngaju are more specific than Indonesian. Dayak Ngaju recognizes not only jitatu (once removed cousin) but also hanjenan and hararue. Hararue means children who share the same great-grandparents. The translator used description technique to describe the meaning of hararue since there is no equivalent term in Indonesia. Naturalized borrowing is one of borrowing techniques. This technique is to borrowing words or expressions from source language by naturalizing them into target language. Mangayau is a tradition in the war conducted by Dayak tribe in the past. The term of mangayau is derived from noun kayau and added by prefix ma-, forming a verb mangayau. In Indonesian version, mangayau is naturalized into Indonesian morphological structure. The word of kayau is preceded by me- to form a verb mengayau in Indonesia.

The last, variant borrowing technique is one of borrowing technique by using another language, yet the form and font are similar to source text. The term of Sangiang in Dayak indigenous belief means god. It is similar to Sang Hyang, in which in Hinduism also refers to god. Hence, the translator uses Sang Hyang as its equivalence. Sang Hyang is considered as a variant of Sangiang as both refer to the same meaning. On the other hand, in DCT translation of IL to EL, only one translation technique is applied, which is pure borrowing. Examples of the data are Ranying Hatalla Langit, Tatum, Mahanteran, Tiwah. Pure borrowing might be a solution to transfer DCT to target language when there are no equivalent words to them. Besides, cultural terms are mostly specific.

Translation shifts in the translation of DCT also occur. Some DCT are translated into common terms which make them no longer cultural terms. It occurs because the translator uses several translation techniques namely generalization, established equivalent, description, and amplification. By those techniques, the translator uses common terms to convey the meaning of DCT. The translation techniques mentioned are used by translator to make the translated DCT acceptable and easy to be understood by the target readers whose culture are different from the culture of the source language. Yet, the use of these translation techniques results from the essence of DCT completely lost. The translation shifts occur in the translation of DCT from DNL to IL. 
Based on the results of data analysis, the researcher concludes that the most appropriate techniques in translating DCT is a double technique namely Pure Borrowing + Addition. Pure Borrowing technique makes the DCT remains a Dayak culture term in the target language text, and the Addition technique makes it comprehensible to target reader by the additional information in parenthesis.

The translation quality assessment focused in this study are different from previous studies. Simarmata (2015) assessed only acceptability aspect of the cultural terms translation from English to Batak Toba. Yet, the acceptability of the translation has a high score which is similar to the present research. Then, Nugrahani (2019) assessed the accuracy and readability of the Javanese culture terms translation into English. It resulted in a low score of accuracy but high in aspects of readability.

\section{Conclusion}

Some translation techniques are identified in DCT translation from DNL to IL. They are pure borrowing, generalization, established equivalent, amplification, naturalized borrowing, variant borrowing, and description. They result in accurate translations as pure borrowing, naturalized borrowing, established equivalent, and variant borrowing are applied. Besides, they reflect less accurate translation since generalization, description, and amplification are used. While there are five data of less accurate translations, the translation of DCT from DNL to IL generally has a good quality.

In translating DCT from IL to EL, the research indicates one technique, namely pure borrowing. This technique results in accurate translations with average score of 3. However, there are four data, representing less acceptable translations. The number of DCT in source text is initially 25 data. In target text (IL), some of them are no longer identified as Dayak cultural terms up to nine data. Consequently, the data for translation analysis from IL to EL are sixteen. This definitely indicates translation shifts, referring to that DCT in source text no longer become DCT in target text.

The research shows the accuracy for Dayak cultural term translation from Dayak Ngaju to Indonesian is 2.80. It indicates that translation is good or accurate. Similarly, the accuracy score of 2,84 represents an acceptable translation.

The data shows that the average score for the accuracy of Dayak cultural term translation from Indonesian to English is 3. It indicates that all data is translated accurately. Meanwhile, the average score for the acceptability is 2,75. It implies that most of translation is acceptable. As a conclusion, translation quality of DCT translation from DNL to IL and IL and EL is good, indicating accurate and acceptable translation.

Finally, a deep cultural understanding will help translators in the process of translating cultural texts. This can be done by conducting cultural observations and interviews with cultural experts. A good understanding of culture will certainly also produce an accurate work of translation so that there is no distortion of cultural meaning in the work of translation. Translating into a foreign language aims to introduce Indonesian language and culture to global society all over the world (Kendenan, 2019). Thus, a translator can maintain the cultural terms to target language by proper translation techniques producing good quality translation. 
Lida Karyani, M.R. Nababan, Sri Marmanto: Translation Analysis on the Dayak Cultural Terms...

\section{References}

Andianto, M. R., Mihing, S., \& Uan, S. (1987). Sastra Lisan Dayak Ngaju. Jakarta: Pusat Pembinaan dan Pengembangan Bahasa, Departemen Pendidikan dan Kebudayaan.

Iper, D., Jumiati, H., \& Limin, D. L. (1997). Pepatah-Petitih dalam Bahasa Dayak Ngaju. Departemen Pendidikan dan Kebudayaan.

Irwan, I., Putra, H. E., \& Rahmadani, R. (2018). Students' Variation In Translating English Passive Voice Into Bahasa Indonesia. Langkawi: Journal of The Association for Arabic and English, 4(2), 91. https:// doi.org/10.31332/lkw.v4i2.897

Jarob, Y., Sujaini, H., \& Safriadi, N. (2016). Uji Akurasi Penerjemahan Bahasa Indonesia - Dayak Taman Dengan Penandaan Kata Dasar dan Imbuhan. Jurnal Edukasi Dan Penelitian Informatika (JEPIN), 2(2). https:// doi.org/10.26418/jp.v2i2.16520

Kendenan, E. S. (2019). A Study of Students ' Subtitling Project on “ Ambilkan Bulan " Movie. Langkawi: Journal of The Association for Arabic and English, 5(1), 26-44.

Molina, L., \& Albir, A. H. (2002). Translation techniques revisited: A dynamic and functionalist approach. Meta, 47(4), 498-512. https:/ / doi.org/10.7202/008033ar

Nababan, M., Nuraeni, A., \& Sumardiono. (2012). Pengembangan Model Penilaian Kualitas Terjemahan (Mangatur Nababan, dkk. Kajian Linguistik Dan Sastra, 24(1), 39-57.

Nahan, A. F., \& Rampai, D. D. (2010). The Ot Danum From Tumbang Miri Until Tumbang Rungan. Palangka Raya: WWF-Indonesia, Pemerintah Provinsi Kalimantan Tengah.

Nugrahani, D., Nababan, M. R., Santosa, R., \& Djatmika. (2019). Translating Javanese Culture Expressions in a Novel: Techniques and Quality. Journal Of Social Studies Education Research, 10(2), 323-343.

Ristati. (2006). Sistem Fonologi Bahasa Dayak Ngaju. Universitas Gajah Mada.

Sigiro, E. P., Suryanyahu, A., \& et al. (2013). Tata Bahasa Dayak Ngaju. Palangka Raya: Balai Bahasa Provinsi Kalimantan Tengah.

Simarmata, N. B. (2015). Analisis Teknik Penerjemahan dan Kualitas Terjemahan IstilahIstilah Budaya Bahasa Ingris ke dalam Bahasa Batak Toba yang Terdapat dalam Dubbing Film Jesus. Universitas Sebelas Maret.

Spradley, J. P. (2006). Metode Etnografi. Yogyakarta: Tiara Wacana.

Suryanyahu, A. (2009). Paralisme Semantik dalam Teks Ritual (Sumpah Adat) Tawur Hasapa. In Antologi Hasil Penelitian Bahasa dan Sastra. Balai Bahasa Provinsi Kalimantan Tengah.

Suryanyahu, A., \& Dkk. (2013). Kamus Dwibahasa Dayak Ngaju-Indonesia. Palangka Raya: Balai Bahasa Provinsi Kalimantan Tengah.

Sutopo, H. B. (2002). Metode Penelitian Kualitatif Dasar Teori dan Penerapannya dalam Penelitian. Surakarta: UNS Press.

Tol, Roger, \& Pudentia. (1994). Tradisi Lisan Nusantara: Oral Tradition from the Indonesian Archipelago A Three-Directional Approach. International Conference on Oral History. New York: Columbia University. 